\title{
A ENUNCIAÇÃO dA CANÇÃO POPULAR NOS LIMITES DA NARRATIVIDADE
}

Luiz Tatit

A semiotização dos discursos artísticos que escapam ao universo literário tem sido uma das frentes de atuaçāo da semiótica de hoje. As primeiras incursões foram praticadas, evidentemente, no terreno das artes seculares como a pintura, a arquitetura e até a música que, embora apresentassem problemas de enorme complexidade por diferirem radicalmente da língua natural, mantinham, pelo menos, uma significação homogênea pois que articulada por um único sistema.

O que predomina, entretanto, no nosso século, são os sistemas de significação sincréticos que surgem da combinatória de sistemas simples, quase sempre mediados por processos tecnológicos de produção ou de veiculação. A princípio, a abordagem desses sistemas poderia parecer uma outra etapa de trabalho cujo requisito principal seria exatamente a descrição já resolvida dos sistemas componentes. Verificou-se, porém, que, assim como a análise transfrástica revelou um plano de investigação sêmio-narrativa e sêmio-discursiva que nada tem a ver com a somatória das frases, a descrição dos processos sincréticos de significação também independe das soluções semióticas obtidas por este ou aquele sistema. As interações, as coerções e as compensações mútuas dão aos sistemas de significação que operam em paralelo um outro estatuto de verificação, por vezes, bem distante do campo de análise de seus sistemas componentes.

Para desenvolver o nosso tema, tomaremos aqui como ponto de partida o percurso que vai da instância de enunciação até as etapas máximas de estruturação; tanto no plano do conteúdo como no plano da expressāo, independentemente dos sistemas semióticos que venham percorrê-lolo. Instância de enunciação aqui pode ser considerada a 
situação de comunicaçāo pressuposta por qualquer discurso e sua definição dependeria de uma construçāo semiótica tal que possibilitasse a imediata correlação desta semiose com aquela da língua natural e do mundo natural. Como ainda estamos longe disso, só podemos tomar esta instância como um pressuposto que, por ser comum a todos os processos de significação, se constrói e se enriquece precisamente a partir das descobertas efetuadas pela descrição de inúmeros domínios de significação.

Semiotizando este percurso com os parcos recursos de que já dispomos, poderiamos substituir esses terminais de comunicação entre enunciador e enunciatário por termos de maior funcionalidade narrativa, qual seja, as noções de destinador e destinatário, pois aí teríamos um processo mais dinâmico compreendendo a transferência de objetos de um actante a outro e visando o desencadeamento da ação deste último.

Dentro desta ótica, pretendemos levantar aqui uma reflexão sobre a canção popular. A constatação de que esta constitui um caso de sincretismo de significação advém, primeiramente, de uma abordagem fenomenológica: os elementos mínimos para se identificar algo como canção, no senso comum, é a presença simultânea de pelo menos uma linha lingüística e outra melódica, esta última podendo-se manifestar com maior ou menor apoio músico-instrumental.

$\mathrm{Na}$ trajetória oposta, diremos que a enunciação, ou seu sujeito, se dilui em modalidades disseminadas pelo texto lingüístico e pelo texto melódico ocasionando relaçōes de compatibilidade entre os dois componentes. Neste estágio, podemos descrever as modalidades assinaladas pelo componente lingüístico e avaliá-las em sua concomitância com as curvas melódicas descendentes, ascendentes e suspensivas responsáveis pela/ Asseveração/. Assim, a competência modal dos actantes debreados pela enunciação lingüística é reiterada ou complementada pelo contorno melódico entoativo. 'Grosso modo', se as terminações (tonemas) descendentes indicam asseveração propriamente dita confirmando, portanto, uma competência adquirida, senão através de um/poder/ou/querer/, pelo menos através de um/saber/, as manifestações de não-descendência tonemática devem estabelecer matizes modais retratando perdas, transferências ou outras inúmeras variaçōes no âmbito das competências dos actantes. $O$ próximo estágio, previsto do ponto de vista teórico, comportaria a desmodalização completa tanto do texto lingüístico quanto do texto melódico. Seria o caso de um discurso lingüístico plenamente objetivo e de demonstração, dominado 
pelos mecanismos anafóricos, cuja distância enunciativa corresponde àquela almejada pelo texto científico e, de outro lado, o caso de um discurso melódico trabalhado única e exclusivamente pela sintaxe musical perdendo toda raiz entoativa.

Estas constatações preliminares a respeito da canção popular podem ser projetadas e articuladas pela relação destinador/destinatário de modo a estabelecer a seguinte comunicação: um destinador (na canção, o locutor - compositor ou intérprete -) exercendo função de manipulador persuasivo e munido de modalidades das quais destacamos o /saber fazer/, atinge a competência de um sujeito-destinatário (ouvinte) despertando-lhe um /querer fazer/, processo este já representado em semiótica pela figura da "sedução" (voltaremos a este ponto mais abaixo). Para tanto, o destinador-enunciador manobra, ao mesmo tempo, um percurso lingüístico e um percurso melódico que oscilam de uma sintonia simbiótica (quando próximos à instância de enunciação) até uma defasagem entre si que beira a auto-suficiência (à medida que se afastam da instância de enunciação).

Quando dizemos que a integração entre o componente lingüístico e o componente melódico se torna quase simbiótica ao se aproximar da instância de enunciação, estamos correlacionando esta semiose da canção com a semiose produzida pela língua natural quando em discurso coloquial, pois é característico de ambas as semioses a produção de uma texto dêitico. $\mathbf{O}$ emprego de imperativos, vocativos, interjeições, advérbios, etc., associado a uma produção melódica adequada, ecoa como um fragmento de discurso coloquial, onde o elemento lingüístico e sua entoação exercem, em comunicação normal, a mesma função informativa. Do ponto de vista da melodia, esta correlação semiótica entre um contorno melódico da canção e um contorno entoativo do discurso lingüístico oral corresponde à figurativização melódica. As figuras melódicas coincidem, assim, com os dêiticos lingüísticos.

O texto da canção popular é um texto modalizado por excelência. Seu equilíbrio é mantido pelos mecanismos de debreagem do componente lingüístico em contraposição com a ação de embreagem exercida pelo componente melódico. Isto significa que, para cada instauração lingüistica do enunciado, há um retorno melódico-entoativo à enunciação (mesmo quando a frase lingüística pertence a um actante num tempo e num espaço diferentes dos da enunciação, a entoação melódica presentifica a enunciação pelo seu vínculo sempre direto com o sujeito enunciativo). Quando o próprio discurso lingǘstico opera uma 
embreagem enunciativa, sua ressonância com o perfil melódico provoca o efeito de deitização (caso do imperativo, p/ ex.)

Voltando agora à nossa narrativização da enunciação da cançāo popular e lembrando que o enunciador (locutor) exerceria no modelo a função de destinador manipulador e o enunciatário (ouvinte) a função de sujeito destinatário da comunicação, levantaremos algumas considerações a respeito da ação persuasiva que caracteriza esta relação destinador/destinatário.

Este último estágio, evidentemente, inexiste no universo da canção popular, pois que o tratamento de um discurso lingüístico em simultaneidade com um discurso melódico se converte, quase necessariamente, em texto modalizado. A melodia de canção, pela correlaçāo que guarda com a melodia entoativa, apresenta-se sempre como um índice do sujeito enunciativo que sacrifica a objetividade do texto. Em vista disso, preferimos dizer que o ponto máximo de objetividade atingido pelo componente lingüístico da canção é aquele da "tematização" ou de despojamento figurativo, pois a característica da ordenação temática é exatamente a de ser articulada por uma lógica de modalidades (RASTIER, 1983, 14). Do mesmo modo, a ordenação melódica de expressão, que consiste basicamente na criação e na reiteração de motivos, constituirá também um percurso temático de expressão. Aliás, tal percurso seria o responsável pela formação dos gêneros do cancioneiro: "samba" "bolero" "rock" etc.

Temos, portanto, um percurso enunciativo que se vai processando por debreagens e por anaforizações crescentes, num movimento de desdeitização e desfigurativização melódica em proveito de uma modalização dos dois componentes e, em sentido inverso, um percurso de de-enunciação marcado pelas embreagens e pelas deitizações, num movimento de destematização lingüística e melódica, passando pela modalização e atingindo, novamente, a deitização/figurativização melódica.

Dificilmente teríamos a oportunidade de verificar numa canção a exclusividade de apenas um dos momentos enunciativos mencionados. A ocorrência freqüente é a alternação de predominância desses momentos no decorrer de uma mesma canção. Diriamos então que, dentro do equilíbrio das compatibilidades modais entre componente lingüístico e componente melódico, o destinador de uma canção sobremodaliza (ou “seduz") o sujeito destinatário (ouvinte) através da presença dosada, em termos de intensidade, dos três níveis limites de ordenação enunciativa comentados acima. Ou seja, a atuação dos 
dêiticos e das figuras melódicas trazem subsídios para a difícil estruturação da instância de enunciação e significam, sobretudo, a transparência do sujeito enunciador (destinador). Aqui, pode-se dizer, se instala a "sedução" propriamente dita, pois o destinador desperta o /querer/ do destinatário em função de si próprio (ou em funçāo da própria figura). A ordenação de conteúdo temático-modal assegura uma manipulação cognitiva na medida em que o sujeito-destinatário se convence dos conteúdos obtidos pela integração adequada entre texto lingüístico e texto melódico. É o caso do ouvinte que se entusiasma com o relato lingüístico da canção. O que persuade não é a atuação isolada do componente lingüístico, mas sim este componente modalizado pela melodia. Por fim, a ordenação de expressão temática (esta ordenação de expressāo não é apenas melódica, mas se estende também às aliterações fônicas do discurso lingüístico) responde por uma manipulação pragmática, talvez mais ao nível da figura "tentação" pois o destinador parece exercer um /poder fazer/ o destinatário /querer/. Este /querer/ se manifestará, evidentemente, por algum tipo de fazer: dançar, movimentar-se ou, simplesmente, empolgar-se com a percepção físico-acústica de uma regularidade que conduz ao reconhecimento de um gênero do seu agrado: um "samba", um "rock" etc.

Em outras palavras, o que se observa comumente é a conjugação subjacente da ordenação de expressão (temático-melódica) com a ordenação de conteúdo (temático-modal) e com a ordenação dêiticofigurativa (revelando aspectos do sujeito enunciativo) que provoca no enunciatário-ouvinte a "euforia" de sentir um relato lingüístico ligado a um gênero melódico (um samba, por ex.) e ligado a um locutor (intérprete), todos inteiramente de seu agrado.

A cançāo popular como discurso estético conta, no mínimo, com esses três recursos "euforizantes", que poderiam ser formalizados pela relação funcional entre um destinador e um destinatário-sujeito narrativo no quadro de uma comunicação de objetos modais.

\section{Bibliografia especifica:}

BARROS, D.L.P. Vers une semiotique de la manipulation In: Le Bulletin, n. 1 - ENESS - CNRS, Paris, INLF, 1977.

CASTELLANA, M. (org.) "Semiotique musicale" In: Actes semiotiques Bulletin, 28 ENESS - CNRS, Paris, INLF, 1983

FLOCH, J.M. (org) “Semiotiques syncretiques” In: Actes semiotiques Bulletin, 27, id., 1983

GREIMAS, A. J. “De la figurativité” In: Actes semiotiques Bulletin, 26 - ENESS CNRS, Paris, INLF. 1983. 
\& COURTES, J. Sémiotique. Dictionnaire raisonné de la théorie du langage. Paris, HACHETTE, 1979

PARRET, H. "La mise en discours in tant que déictisation et modadisation" In: Langages, 70, Paris, Larousse, 1983.

RASTIER, Fr. "Le problème du figuratif et l'impression référencielle" In: Aıtes semiotique - Bul., 26, id., 1983

TARASTI, E. "De l'interpretation musicale" In: Actes Semiotiques Documents. 42 ENESS CNRS, Paris, INLF, 1983.

TATIT, L. Por uma semiótica da canção popular. São Paulo. FFLCH USP. 1982 (Dissertação de Mestrado Cát. lingüística)

TOMĀS, N.Manual de entonación Española. 3' ed., México. D. F. Coleccion Malaca. 1966. 